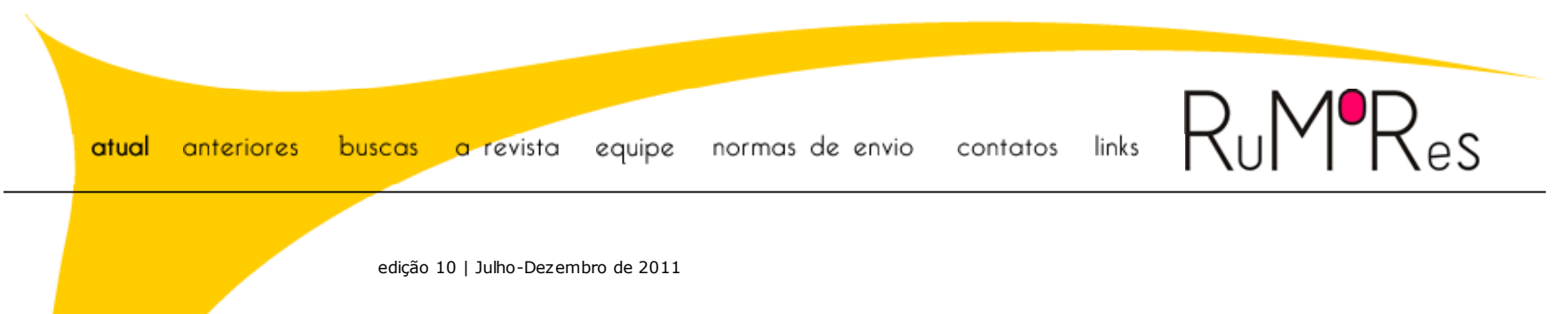

Editorial

\title{
Práticas na linguagem e as manifestações da alteridade
}

RuMoRes, revista científica online dedicada aos estudos de comunicação, linguagem e mídias, chega à sua edição comemorativa, aquela de número 10, marcando seu quinto ano de atuação. Com visual atualizado pelo cuidadoso trabalho da designer Paula Paschoalick, o site foi reformulado de modo a acompanhar as tendências estéticas funcionais do meio onde se insere. Dessa maneira, prima pela acessibilidade às informações: a chamada de trabalhos, as informações para o envio de textos e especialmente a visualização da edição atual. As edições anteriores foram preservadas em nosso banco de dados e continuam disponíveis através do sistema de busca.

Esperamos que essa transformação seja convidativa para a fruição da especial seleção de textos que compõem o presente número. Abrimos as leituras com um Dossiê centrado na averiguação dos limites e possibilidades das práticas jornalísticas e imagéticas. Mayra Rodrigues Gomes e Nara Lya Cabral situam o relacionamento consonante entre a prática jornalística e a opinião pública. Ingressados que estamos na especificidade da prática jornalística, Gislene Silva e Flávia Dourado Maia pensam em como estudar tal produção através de um protocolo metodológico próprio, desenvolvido pelas autoras.

Da preocupação metodológica voltada à produção jornalística passamos a uma apropriada às práticas da imagem. Partimos através de um recorte considerando alteridade, raça e sexo para pensar, com Ângela Prysthon, recorrências e diferenças em relação à visão do outro no cinema britânico. Do formato fílmico tomado pelo outro, vamos à atenção com a poética das imagens no trabalho de Felipe Muanis, que analisa vinhetas institucionais da Rede Globo e da MTV para polemizar a idéia de interrupção das metaimagens televisivas. Entendemos a presença do outro nos filmes, incluída narrativamente ou podemos pensar, ainda, na esfera de sua recepção. Fábio Akhras e Lilian Santos, preocupados com a questão do letramento (literacy) observam a linguagem cinematográfica, a televisiva e os mecanismos da publicidade, entre outros parâmetros, para a análise da recepção de mídia por crianças brasileiras.

Iniciamos a seção de Artigos da edição com a procura por algo singular nas mídias: Beatriz Marocco visualiza outras formas da confissão associando a prática da entrevista aos novos ambientes digitais e Emília Simão faz casar a mesma dualidade entre práticas sociais e novos meios, associando a eles outros termos para pensar o transe espiritual.

Passando da busca do novo em termos de experiência midiática para o encontro com tais experiências voltadas a um público jovem, Sueli Soares estuda aspectos de obras cinematográficas sinalizadoras de novas formas de encantamento e permanência dos mitos em torno da infância e da racionalidade. Maria Antonieta Tourinho, por sua vez, ajuda-nos a pensar como a arte cinematográfica pode contribuir especificamente no ensino de história, sendo levada para o ambiente escolar.

Ampliando a perspectiva de modo a passar de um tipo específico de público para a questão da apropriação do outro nos discursos, retomamos e reforçamos nesta edição a questão aberta no Dossiê, agora sob a perspectiva de autoria, alteridade e a interatividade. Jeanete Moussa Alma estuda, em seu artigo, a ação de escolha possível de produtos cosméticos por parte de esteticistas. Os movimentos para legitimar uma posição autoral ligada a efeitos de autoridade e de autorização são trabalhados,em relação ao documentário, por Mariana Duccini. Renata Malta concentra-se, por sua vez, em novos formatos para o meio televisivo visando pensar as relações de interatividade nos modos de fazer televisão.

Apartando-se das formas do outro nos discursos, migramos para as possibilidades de seu reconhecimento na relação com os registros do real e do ficcional. Paula Guimarães Simões investe na recepção da telenovela e de vivências amorosas por parte de seu público. Jennifer Jane Serra chega à seara do documentário de animação apontando seu hibridismo com o cinema do real e contrastando-o com o registro ficcional. 
Escapando da dualidade entre real e ficcional dirigimo-nos para um processo de fragmentação identificado nos ambientes digitais. Débora Faccion estuda como resta o estatuto das artes e suas possibilidades estéticas nesse ambiente. Geraldo de Lima procura estabelecer os imaginários fílmicos do que seja o ambiente cibercultural. Gabriela Nóra, por sua vez, olha para uma mídia tradicional, o jornalismo impresso, buscando entender os efeitos de transformação do digital sobre ela.

Voltando-se ao ambiente de manifestações coletivas, Bruno Sampaio Garrido preocupa-se com o culto religioso midiatizado pela televisão,enquanto Jandré Corrêa Batista volta-se para a fotografia como forma de registro etnográfico dentro da perspectiva discursiva.

Pensandoas possibilidades do espaço da biblioteca como ambiente (des)favorável para a comunhão pública, encerramos a edição de RuMoRes com Resenhas de Maria Aparecida Laet para o livro Bibliotecas públicas, bibliotecários e censura na Era Vargas e Regime Militar, de Bárbara Júlia Menezello Leitão, e de Maria Noemi Araújo para o livro Ó, de Nuno Ramos.

Mais do que compor esta décima edição, esperamos que os textos nela reunidos possibilitem a retomada de temáticas anteriormente tratadas pela revista e daquelas que se seguirão. Boa leitura!

Rosana de Lima Soares e Andrea Limberto - dezembro de 2011 